\title{
A Novel Cyclophilin B Gene in the Red Tide Dinoflagellate Cochlodinium polykrikoides: Molecular Characterizations and Transcriptional Responses to Environmental Stresses
}

\author{
Sofia Abassi, ${ }^{1}$ Hui Wang, ${ }^{1}$ Bum Soo Park, ${ }^{2}$ Jong-Woo Park, ${ }^{3}$ and Jang-Seu Ki ${ }^{1}$ \\ ${ }^{1}$ Department of Biotechnology, Sangmyung University, Seoul 03016, Republic of Korea \\ ${ }^{2}$ Institute of Natural Sciences, Sangmyung University, Seoul 03016, Republic of Korea \\ ${ }^{3}$ Ocean Climate and Ecology Research Division, National Institute of Fisheries Science, Busan 46083, Republic of Korea \\ Correspondence should be addressed to Jang-Seu Ki; kijs@smu.ac.kr
}

Received 29 April 2017; Accepted 13 September 2017; Published 26 October 2017

Academic Editor: Atanas Atanassov

Copyright (C) 2017 Sofia Abassi et al. This is an open access article distributed under the Creative Commons Attribution License, which permits unrestricted use, distribution, and reproduction in any medium, provided the original work is properly cited.

\begin{abstract}
The marine dinoflagellate Cochlodinium polykrikoides is one of the most common ichthyotoxic species that causes harmful algal blooms (HABs), which leads to ecological damage and huge economic loss in aquaculture industries. Cyclophilins (CYPs) belong to the immunophilin superfamily, and they may play a role in the survival mechanisms of the dinoflagellate in stress environments. In the present study, we identified a novel cyclophilin gene from C. polykrikoides and examined physiological and gene transcriptional responses to biocides copper sulphate $\left(\mathrm{CuSO}_{4}\right)$ and sodium hypochlorite $(\mathrm{NaOCl})$. The full length of $C p C Y P$ was $903 \mathrm{bp}$, ranging from the dinoflagellate splice leader (DinoSL) sequence to the polyA tail, comprising a $639 \mathrm{bp}$ ORF, a $117 \mathrm{bp} 5^{\prime}$-UTR, and a $147 \mathrm{bp}$ $3^{\prime}$-UTR. Motif and phylogenetic comparisons showed that CpCYP was affiliated to group B of CYP. In biocide stressors, cell counts, chlorophyll $a$, and photosynthetic efficiency $(F v / F m)$ of $C$. polykrikoides were considerably decreased in both exposure time- and dose-dependent manners. In addition, $C P C Y P$ gene expression was significantly induced after $24 \mathrm{~h}$ exposure to the biocide-treated stress conditions. These results indicate an effect of the biocides on the cell physiology and expression profile of $C p C Y P$, suggesting that the gene may play a role in environmental stress responses.
\end{abstract}

\section{Introduction}

Dinoflagellate algae are eukaryotic protists which exhibit a great diversity of form and are the most important primary producer in aquatic environments. However, some species (e.g., Alexandrium tamarense, Akashiwo sanguinea, and Cochlodinium polykrikoides) can grow very fast when environmental conditions are appropriate, leading to the formation of harmful algal blooms (HABs). These events cause serious environmental damage on fisheries and aquatic ecosystems [1]. The dinoflagellate C. polykrikoides is one of the notorious HAB species, and it has expanded oceanic distributions worldwide $[2,3]$. In addition, red tides caused by this species can produce ichthyotoxins causing deleterious impacts on the marine ecosystem and aquaculture industries and lead consequently to huge economic losses [4-6].

In molecular aspects, dinoflagellates have extraordinary genomic features, such as large nuclear genome size, fewer histones, permanently condensed and liquid-crystalline chromosomes, $\sim 70 \%$ replacement of thymine with 5hydroxymethyluracil, and extensively methylated nucleotides $[7,8]$. Even their genes are expressed to be matured in a transsplicing manner in mRNA processing reactions [9], and some are posttranscriptionally or translationally regulated [10]. For these reasons, they have been widely used in studies related to gene and genome researches, protist molecular evolution, and even recent ecotoxicological assessments [11-15].

Cyclophilins (CYPs) are a subgroup of a large family of proteins called immunophilins, with a peptidyl-prolyl cistrans isomerase (PPIase) activity [16]. PPIases catalyze the cis-trans isomerization of proline imidic peptide bonds and regulate protein folding and maturation. They are found in a large variety of organisms and thus are highly conserved. All CYPs share a common domain of approximately 109 amino acids, the cyclophilin-like domain (CLD), surrounded by domains unique to each member of the family that 
is associated with subcellular compartmentalization and functional specialization [17]. CYPs can be found in most cellular compartments of most tissues and encode unique functions. They also have varying degrees of affinity for the immunosuppressive drug CsA, a cyclic 11-amino-acid peptide produced by the fungus Tolypocladium inflatum. Cyclophilin A (CYP A), in particular, is the major intracellular receptor for CsA [18]. The $18 \mathrm{kDa}$ archetypal CYP A is cytosolic and is found in all tissues in mammals, whereas other cyclophilins, whether they have a CLD alone or in combination with other domains, are found in the endoplasmic reticulum (ER), the mitochondria, or the nucleus. In mammals, CYP A and CYP 40 are cytosolic, whereas other groups, CYP B and CYP C, have amino-terminal signal sequences that target them to the ER protein secretory pathway $[16,19]$. These findings show that CYPs are divided into groups (CYP A, CYP B, CYP C, etc.) based on their size and their target location [20], and thus they may have different roles rather than already-known housekeeping functions.

Recent studies have shown that CYPs belong to different subcellular compartments, and they have been found to have diverse roles, including detoxification of reactive oxygen species (ROS), protein maturation processing, immune response, gene regulation by microRNA activity, and spliceosome assembly [21]. Besides the PPIase and protein chaperone activities (housekeeping functions), CYPs function in mitochondrial metabolism, apoptosis, immunological response, inflammation, and cell growth and proliferation [22-24]. Regarding algae, Wu et al. [25] studied the expression of some genes in the green seaweed Ulva fasciata and revealed that CYP was involved in redox homeostasis and antioxidant defense. In addition, the role of CYP in response to stress was previously reported from the red algae Porphyra haitanensis [26]. Moreover, the CYPs could play a critical role in the regulation of cnidarian-algal symbiosis [27]. Perez and Weis [28] suggested that CYP may help in the regulation of symbiosis between the sea anemone Aiptasia pallida and intracellular dinoflagellates. Interestingly, their study showed that the dinoflagellate symbionts (zooxanthellae) became heat sensitive when CYP was inhibited by cyclosporine and showed loss of the symbionts from the host tissues [28]. More recently, we found that the dinoflagellate Prorocentrum minimum has stress responsive functions in cells exposed to heavy metals and organic contaminants [29]. These findings suggest that dinoflagellate CYPs may be considered as a sensitive indicator for environmental contaminants; however, their stress responsive involvement is not tested widely by using other dinoflagellates. In addition, different types of CYPs (e.g., CYP A, CYP B, CYP C, and CYP D) have not been characterized by comparison to those of other eukaryotes to date. Hence, discovering more information about CYP gene structure and expressional responses in other species shall be appropriate and informative, which is beneficial to understand the gene regulation mechanisms in adaptive, survival strategies of dinoflagellates.

In the present study, we determined the full sequence of a type CYP gene from the dinoflagellate Cochlodinium polykrikoides (CPCYP). We performed a series of analyses to characterize $C P C Y P$ gene and genomic features, including motif searches, intergenic spacer (IGS), deduced protein sequence comparisons, and phylogenetic relationships. In addition, we examined the transcriptional response of $C P C Y P$ under stress conditions using two biocides: $\mathrm{CuSO}_{4}$ and $\mathrm{NaOCl}$.

\section{Materials and Methods}

2.1. Cell Culture. The strain (Cp-01) of C. polykrikoides was obtained from the National Institute of Fisheries Science (Busan, Korea). The cell cultures were maintained in $\mathrm{f} / 2$ medium at $20^{\circ} \mathrm{C}$ in a $12: 12 \mathrm{~h}$ light: dark cycle with a photon flux density of approximately $65 \mu \mathrm{mol}$ photons $\mathrm{m}^{-2} \mathrm{~s}^{-1}$.

2.2. RNA Extraction, cDNA Synthesis, and DNA Extraction. C. polykrikoides cultures were harvested by centrifugation at $3500 \mathrm{rpm}$ for $5 \mathrm{~min}$, frozen immediately in liquid nitrogen, and stored at $-80^{\circ} \mathrm{C}$ until RNA extraction. The cells were physically broken by freeze-thawing in liquid nitrogen and homogenized by Mini-Bead beater (BioSpec Products Inc., Bartlesville, OK) with zirconium beads (diameter: $0.1 \mathrm{~mm}$ ). Total RNA was isolated using TRIzol (Invitrogen, Carlsbad, CA) and purified by Mini Spin Columns of RNeasy Mini Kit (Qiagen, Valencia, CA).

For the first-strand cDNA, 2 different cDNA synthesis kits were employed: TOPscript ${ }^{\mathrm{TM}} \mathrm{cDNA}$ Synthesis Kit for the gene cloning of CpCYP and TOPscript RT DryMIX (dN6 plus) for gene expression study. Then, the first-strand cDNA templates were diluted 1:10 with nuclease-free water for use in subsequent analyses. Total genomic DNA was extracted from C. polykrikoides following the cetyltrimethylammonium bromide (CTAB) method [30].

2.3. Determination of CYP Gene Sequences. The full length of $C P C Y P$ sequence was determined by rapid amplification of cDNA ends (RACE). Partial gene sequences of CPCYP were taken from an expressed sequence tags (ESTs) database of $C$. polykrikoides and were used to design the primers for the full-length amplification of CPCYP (Table 1). The $3^{\prime}$ - and $5^{\prime}$-untranslated regions (UTRs) of $C P C Y P$ were determined by using the $3^{\prime}$ - and $5^{\prime}$-RACE, respectively. For the RACE, the primary and secondary PCRs conditions were as follows: predenaturation at $96^{\circ} \mathrm{C}$ for $10 \mathrm{~min} ; 35$ cycles of $95^{\circ} \mathrm{C}$ for $30 \mathrm{~s}, 55^{\circ} \mathrm{C} / 58^{\circ} \mathrm{C}$ for $30 \mathrm{~s}$, and $72^{\circ} \mathrm{C}$ for $80 \mathrm{~s}$; and extension at $72^{\circ} \mathrm{C}$ for $10 \mathrm{~min}$, respectively. Positive core PCR products were purified, cloned into pTOP TA V2 vector (Enzynomics, Daejeon, Korea), transformed into E. coli competent cells, and subjected to sequencing. CPCYP full-length sequence was validated by PCR with specific primers (Table 1 ). As for the determination of $C P C Y P$ genomic sequence, the used primers were designed according to cDNA sequence (Table 1).

2.4. CPCYP Characterization and Phylogenetic Analyses. The similarities of CPCYP aa sequences with those of other species were assessed by using BioEdit 7.0.5.3 [31]. The signal peptide prediction, proteins motifs, and conserved domain of $C P C Y P$ protein were analyzed using online servers and databases, including InterPro 62.0 (http://www.ebi.ac.uk/interpro/), SignalP 4.1 (http://www.cbs.dtu.dk/services/SignalP/), PROSITE (http://prosite.expasy.org/), Compute pI/Mw tool (http://web .expasy.org/compute_pi/), and NCBI Conserved Domain Database (https://www.ncbi.nlm.nih.gov/Structure/cdd/wrpsb.cgi). 
TABLE 1: The primers used in the present study.

\begin{tabular}{|c|c|c|}
\hline Primer name & Nucleotide sequence $\left(5^{\prime} \rightarrow 3^{\prime}\right)$ & Remarks \\
\hline 5-SL & CCGTAGCCATTTTGGCTCAAG & $5^{\prime}$-RACE \\
\hline CpCyp5R1 & TGTCCTTGCCAGCATTGG & $5^{\prime}-\mathrm{RACE}$ \\
\hline CpCyp5R2 & CGTCTTGGGCACCTTCTT & $5^{\prime}-\mathrm{RACE}$ \\
\hline B25 & GACTCTAGACGACATCGA & $3^{\prime}$-RACE \\
\hline B26 & GACTCTAGACGACATCGA(T) ${ }_{18}$ & $3^{\prime}$-RACE \\
\hline CpCypF1 & CATGACGATGGTGTTGCTAAG & $3^{\prime}$-RACE/genomic DNA/full length \\
\hline CpCypF2 & GTTGCTAAGGGGACTATTTGC & $3^{\prime}-\mathrm{RACE} /$ full length \\
\hline СрСур3F3 & AAGAAGGTGCCCAAGACG & Full length \\
\hline CpCypR1 & GTTGAGCGTGCCCTTGTA & Genomic DNA/full length \\
\hline CpCypR0 & GACAACTCACAGCTCCTCGT & Genomic DNA/full length \\
\hline CpCypR3 & CACATGGCAAATAGTCCCCT & Intergenic DNA \\
\hline CpCypF3 & AGCCGTACAAGGATGCCT & Intergenic DNA \\
\hline CpCypR4 & CTTAGCAACACCATCGTCATG & Intergenic DNA \\
\hline CpCypF4 & GCTTTCAACGAGGAGCTGT & Intergenic DNA \\
\hline CpCypR5 & TTGATGACGCGGTGGAAC & RT-PCR \\
\hline CpCypF5 & TCTACGGCAAGAAGGTCC & RT-PCR \\
\hline Cp-TUA2-F2 & TTCTCGCGCATCGACCACAAG & RT-PCR \\
\hline Cp-TUA2-R2 & TCCATACCCTCGCCGACATAC & RT-PCR \\
\hline
\end{tabular}

Phylogenetic analysis of CpCYP and other CYPs was performed in MEGA5 [32], using the neighbor-joining (NJ) method [33]. A bootstrap consensus tree inferred from 1,000 replicates was adopted to represent the evolutionary history of the taxa analyzed [34]. The tree was drawn to scale, with branch lengths in the same units as those of the evolutionary distances used to infer the phylogenetic tree. The evolutionary distances were computed using the JTT matrix-based method [35] and were in the units of the number of amino acid substitutions per site.

2.5. Toxicant Treatments and Photosynthesis Efficiency. Exponential phase cells were used for toxicant treatments. Typical toxicants and biocides $\mathrm{CuSO}_{4}$ (cat. number C1297, Sigma, $\mathrm{MO}$ ) and $\mathrm{NaOCl}$ (cat. number 425044, Sigma, MO) were employed in the present study.

The maximal photosynthesis efficiency $(\mathrm{Fv} / \mathrm{Fm})$ was assessed for different doses of toxicants. Before measuring the fluorescence for $\mathrm{Fv} / \mathrm{Fm}$, all the samples were allowed to adapt in the dark for $25 \mathrm{~min}$. The fluorescence efficiency rates were measured using a Handy Plant Efficiency Analyser fluorometer (Handy PEA fluorimeter; Hansatech Instruments Ltd., King's Lynn, UK). The basic fluorescence parameters [36] are as follows:

Fo: minimal fluorescence in the dark-adapted state

Fm: maximal fluorescence in the dark-adapted state

$F v$ : variation in fluorescence

$F v / F m=(F m-F o / F m):$ maximal quantum yield of PS II photochemistry

2.6. Gene Expression and Statistical Analysis. The dose effects of toxicants $\left(\mathrm{CuSO}_{4}\right.$ and $\left.\mathrm{NaOCl}\right)$ on $C P C Y P$ transcriptional expression were tested using C. polykrikoides cultures treated with a series of concentrations of each toxicant. Different concentrations $\left(0.05,0.1,0.2,0.5\right.$, and $\left.1.0 \mathrm{mgL}^{-1}\right)$ were chosen considering the $\mathrm{EC}_{50}$ values of the biocides [37]. The treated and untreated cultures were harvested at $24 \mathrm{~h}$ for the analysis. RNA extraction and cDNA synthesis were described above. All quantitative real-time polymerase chain reactions (qRTPCRs) were performed with TOPreal ${ }^{\mathrm{TM}}$ qPCR $2 \mathrm{x}$ PreMIX (TOP, Enzynomics, Korea) in a CFX96 Real-Time PCR Detection System (Bio-Rad, Hercules, CA). The qRT-PCR conditions were as follows: $4 \mathrm{~min}$ at $50^{\circ} \mathrm{C}$ and $10 \mathrm{~min}$ at $95^{\circ} \mathrm{C}$, followed by 40 cycles of $10 \mathrm{~s}$ at $95^{\circ} \mathrm{C}, 15 \mathrm{~s}$ at $60^{\circ} \mathrm{C}$, and $15 \mathrm{~s}$ at $72^{\circ} \mathrm{C}$. All reactions were performed in triplicate, and the mean value was calculated. The specificity of the amplification was verified through the analysis of a melting curve generated by gradually heating the sample from $65^{\circ} \mathrm{C}$ to $95^{\circ} \mathrm{C}$. The $\alpha$-tubulin (TUA) was used as an internal control [38]. $C_{T}$ values of qRT-PCR were obtained using CFX96 realtime controlling software (Bio-Rad, Hercules, CA). The fold change relative to control was calculated according to the method of Pfaffl [39].

In addition, the data of gene expression were analyzed using one-way analysis of variance (ANOVA), followed by the Student-Newman-Keuls multiple comparisons test for comparing the relative mRNA expression levels. Data are represented as mean $\pm \mathrm{SD}$, and $P<0.05$ was considered statistically significant.

\section{Results and Discussion}

3.1. CPCYP $c D N A$ and Genomics Characteristics. The cDNA sequence of CPCYP (GenBank number ABX0001) was 903 bp in length (Figure 1), coding 212 amino acids (aa) with a molecular mass of $22.72 \mathrm{kDa}$, and a theoretical isoelectric point of 8.53 .

Upon comparisons of CYP protein motifs, we found that the cyclophilin-type peptidyl-prolyl cis-trans isomerase proteins 


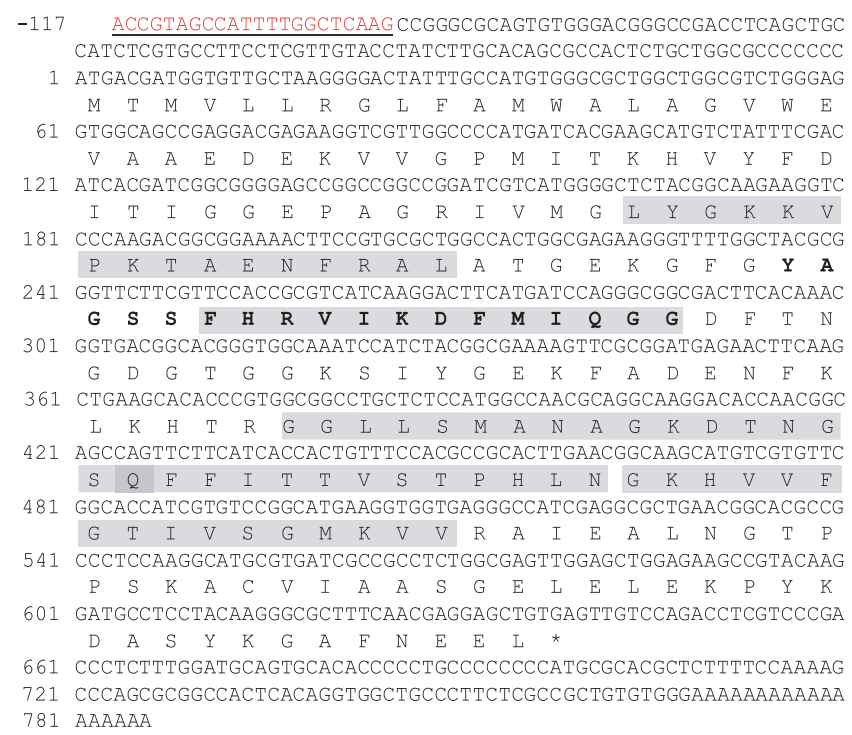

FIGURE 1: Nucleotide and amino acid sequences of CpCYP: DinoSL sequence in red and underlined; five signature motifs of CpCYP are highlighted (55-70, 84-96, 127-142, 142-154, and 155-170 aa). Sequence in bold: conserved site for cyclophilin-type peptidyl-prolyl cis-trans isomerase.

subfamily has a conserved pattern: [FY]-x(2)-[STCNLVA]$\mathrm{x}$-[FV]-H-[RH]-[LIVMNS]-[LIVM]-x(2)-F-[LIVM]-x-Q[AGFT]-G (PROSITE accession number PS00170). Using motif search engines, a similar pattern (79 and 96 aa) was detected in our CpCYP (Figure 1). In addition, we identified a signal peptide of 23 aa located at the end of the $\mathrm{N}$-terminus. Furthermore, a cyclophilin-like domain (CLD) was detected between 31 and 193 aa. Five signature motifs of the cyclophilin-type peptidyl-prolyl cis-trans isomerase were predicted as follows: $55-70,84-96,127-142,142-154$, and 155-170 aa. These patterns were matched with those of other dinoflagellates (Figure 2(b)); the structural differences of CYPs-presence of CLD alone or in combination with other domains (signal peptide, transmembrane domain, etc.) - are the key to determine their localization and therefore the group of CYPs they belong to. For example, PmCYP from Prorocentrum minimum showed a similar cyclophilins family conserved sequence and had five signature motifs; however, instead of a signal peptide, PmCYP had a cytoplasmic signal sequence predicting its cytoplasmic location [29].

As for the location of the gene coding for $C p C Y P$, the presence of DinoSL sequence indicates that the gene is encoded in the nuclear genome of C. polykrikoides [9]. However, the presence of the $\mathrm{N}$-terminal signal sequence in our CPCYP gene indicates that it is targeted to the ER protein secretory pathway $[16,19]$.

Genomic regions of $C P C Y P$ were amplified by PCR, and their sequences were compared to that of the cDNA. As a result, no intron was presented in the $C P C Y P$ coding genome (Figure 2(a)), which correlates with previous results showing that dinoflagellate genes contain very few or lack introns completely [40, 41]. In addition, CYP coding manner was investigated by long PCR using TaKaRa LA Taq kit, according to the manufacturer's instructions (the used primers are found in Table 1). However, we did not find any fragments, while this method could amplify intergenic spacer (IGS) regions of heat shock proteins (HSPs) from C. polykrikoides [42]. These results suggest that our CYP gene is present as a single copy and/or in different loci in chromosomes rather than a tandem arrangement.

Previously, 5 groups of cyclophilins were identified in yeast, according to their molecular mass and localization (CYP A, $17 \mathrm{kDa}$ cytosolic protein; CYP B, $20 \mathrm{kDa}$ secretory protein; CYP C, $18 \mathrm{kDa}$ mitochondrial protein; CYP D, $22.8 \mathrm{kDa}$ ER protein; and CYP 4, 33.4 kDa secretory protein) [43]. In mammals, the 5 groups have been suggested as well, comprising CYP A of $18 \mathrm{kDa}$ soluble cytosolic proteins, CYP $\mathrm{B}$ of $22 \mathrm{kDa}$ proteins with signal sequences for ER, CYP C of $23 \mathrm{kDa}$ proteins with ER signal sequences, CYP D of $22 \mathrm{kDa}$ proteins with putative mitochondrial signal sequences, and CYP 40 of $40 \mathrm{kDa}$ proteins with low affinities to CsA [44]. In the dinoflagellates, to date, CYP protein has been isolated in 4 other species (Alexandrium fundyense, Karlodinium veneficum, Pfiesteria piscicida, and Prorocentrum minimum), with no further characterization; herein, we analyzed those sequences and identified 3 groups as follows: CYP A, CYP B to which our $C P C Y P$ belongs, and CYP C (Figure 2(b)). In $P$. piscicida, two groups of CYP have been recognized, suggesting the presence of more than one group in a dinoflagellate species; however, the presence of more CYP groups and their possible interactions are not to be found at present.

\subsection{CрСYP Phylogenetic Relatedness to Other Eukaryotes.} The basic local alignment search tool (BLAST) searches using our CpCYP protein yielded 159 hits which all belonged to eukaryotic organisms. The search also showed that $C p C Y P$ has $76 \%$ identity with CYP of the dinoflagellate Pfiesteria piscicida (ABI14285) and 70\% and 68\% identities with the green algae Micromonas commoda (XP_002508058) and Bathycoccus prasinos (XP_007510149), respectively (Figure 3). 


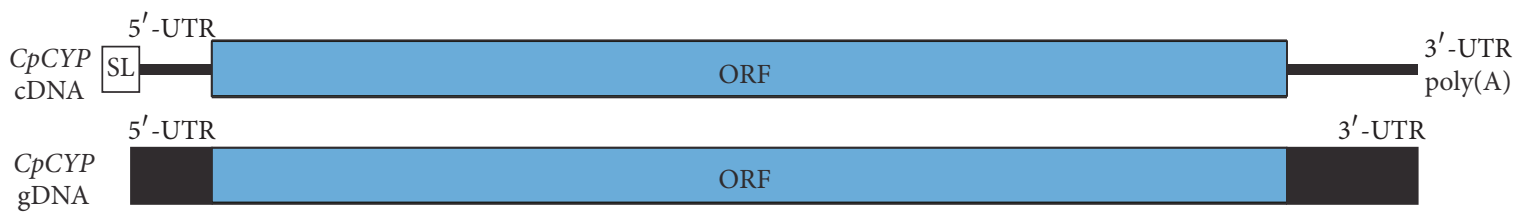

(a)

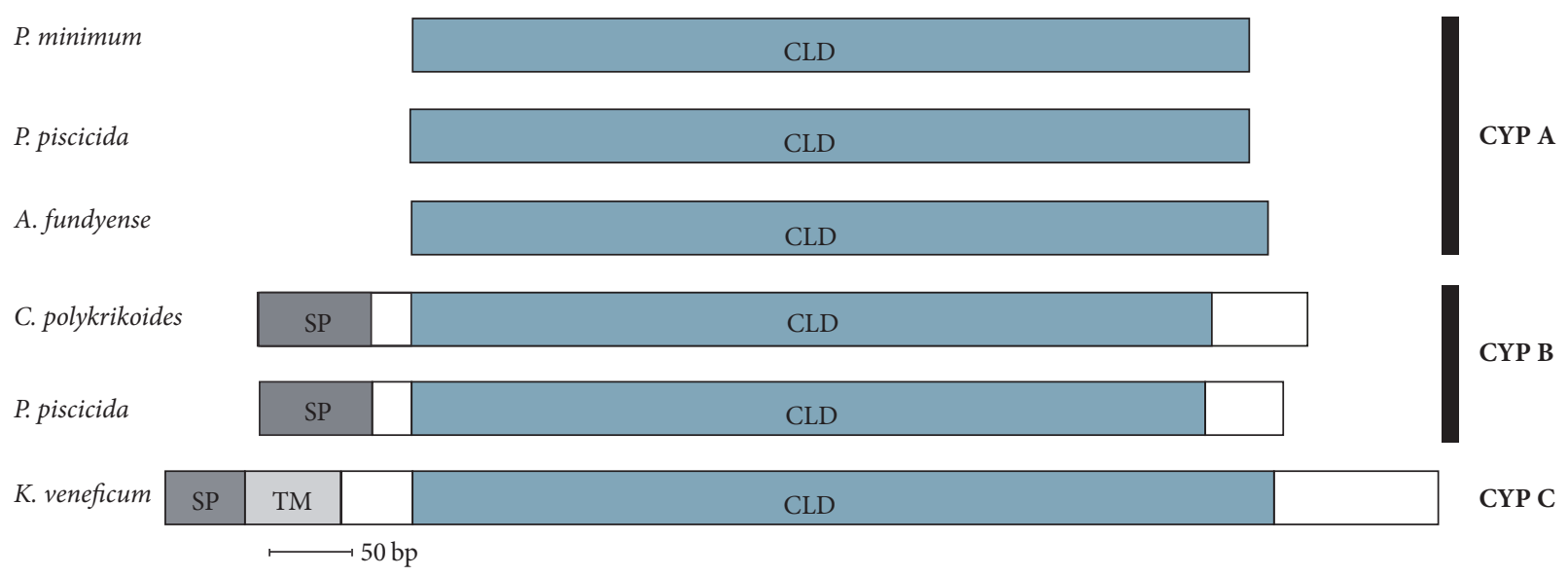

(b)

FIGURE 2: Comparison of cDNA and genomic DNA of CpCYP (a) and its predicted ORF primary structure with other dinoflagellates' CYPs (b). The proteins used here were taken from GenBank database, and their accession numbers are as follows: Prorocentrum minimum (AFD34244); Pfiesteria piscicida CYP A (ABI14282) and CYP B (ABI14285); Alexandrium fundyense (ABO47873); Karlodinium veneficum (ACU45296). SL: spliced leader; ORF: open read frame; SP: signal peptide; TM: transmembrane domain; CLD: cyclophilin-like domain.

C. polykrikoides
P. piscicida
B. prasinos
A. niger
E. pallida
G. theta
A. mexicanus
D. rerio
R. norvegicus

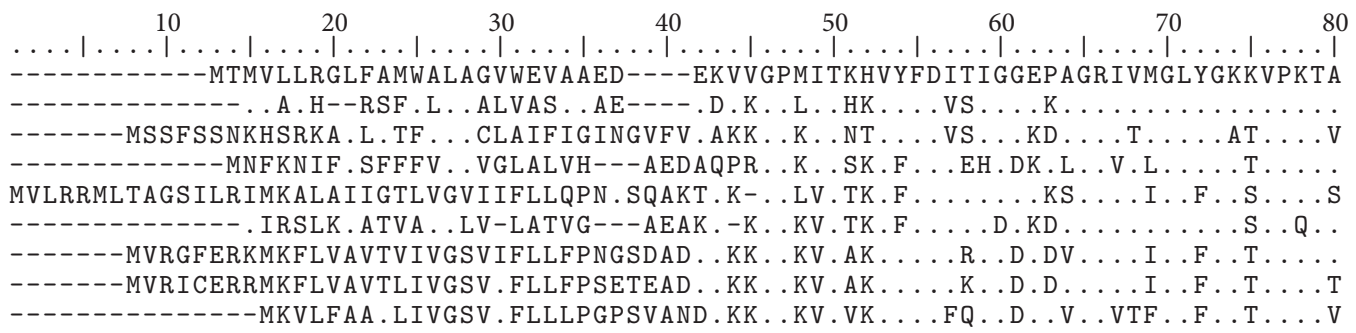

C. polykrikoides

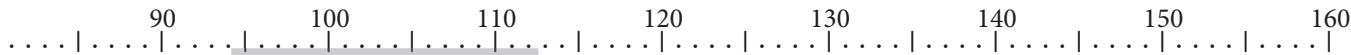

P. piscicida

B. prasinos

A. niger

E. pallida

G. theta

A. mexicanus

D. rerio

R. norvegicus

ENFRAL AT GEKGFGYAGS SFHRV I KDFMIQ GGDFT NGD GT GGKS I Y GEKF ADENFKLKHTRG GLLSMANA GKDTNGSQFF

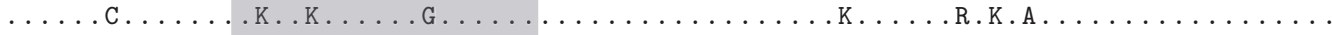

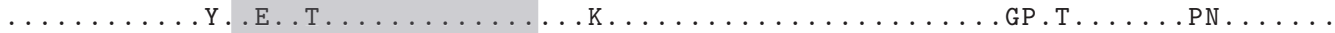

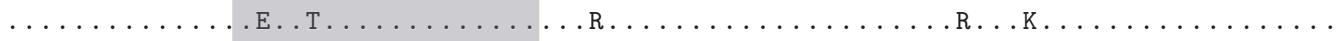

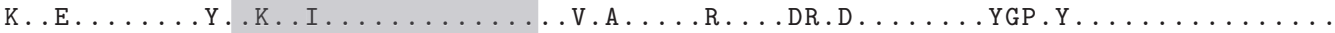

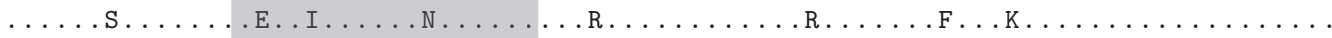

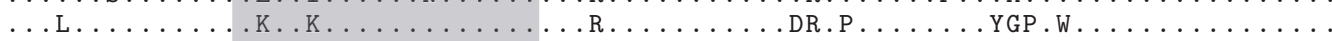

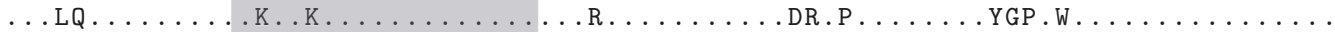

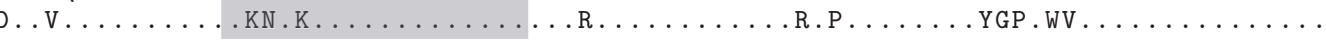

\begin{tabular}{|c|c|}
\hline polykrikoides & PPSKACVIAASGELELEKPYY \\
\hline tis & $. \mathrm{LE} \ldots \mathrm{F} . \mathrm{KM} \ldots \mathrm{EQ}---$. \\
\hline B. $p$ r & . C. . V.SW.D. \\
\hline & EVLE. YEI.AQ. \\
\hline & T.V.D.M.D.T.P.D.FN \\
\hline the & EVLE. .DL.HK. .NSKTDGRDK.E.EVK..K. \\
\hline & K.LE . D . . K . . TKTDGRDK . L.DVT. HEO \\
\hline & \\
\hline orvegicus & SRI \\
\hline
\end{tabular}

FIgURE 3: CPCYP amino acid sequence comparison with CYP B proteins of 8 eukaryotic species; a period (.) represents an aa identical to that of CpCYP, and a dash (-) marks an alignment gap; the cyclophilin-type peptidyl-prolyl cis-trans isomerase conserved site is highlighted in grey box. GenBank numbers of aligned proteins here are as follows: Pfiesteria piscicida ABI14285, Bathycoccus prasinos XP_007510149, Aspergillus niger XP_001401570, Exaiptasia pallida KXJ25954, Guillardia theta XP_005829570, Astyanax mexicanus XP_007235156, Danio rerio NP_998184, and Rattus norvegicus AAC25590. 


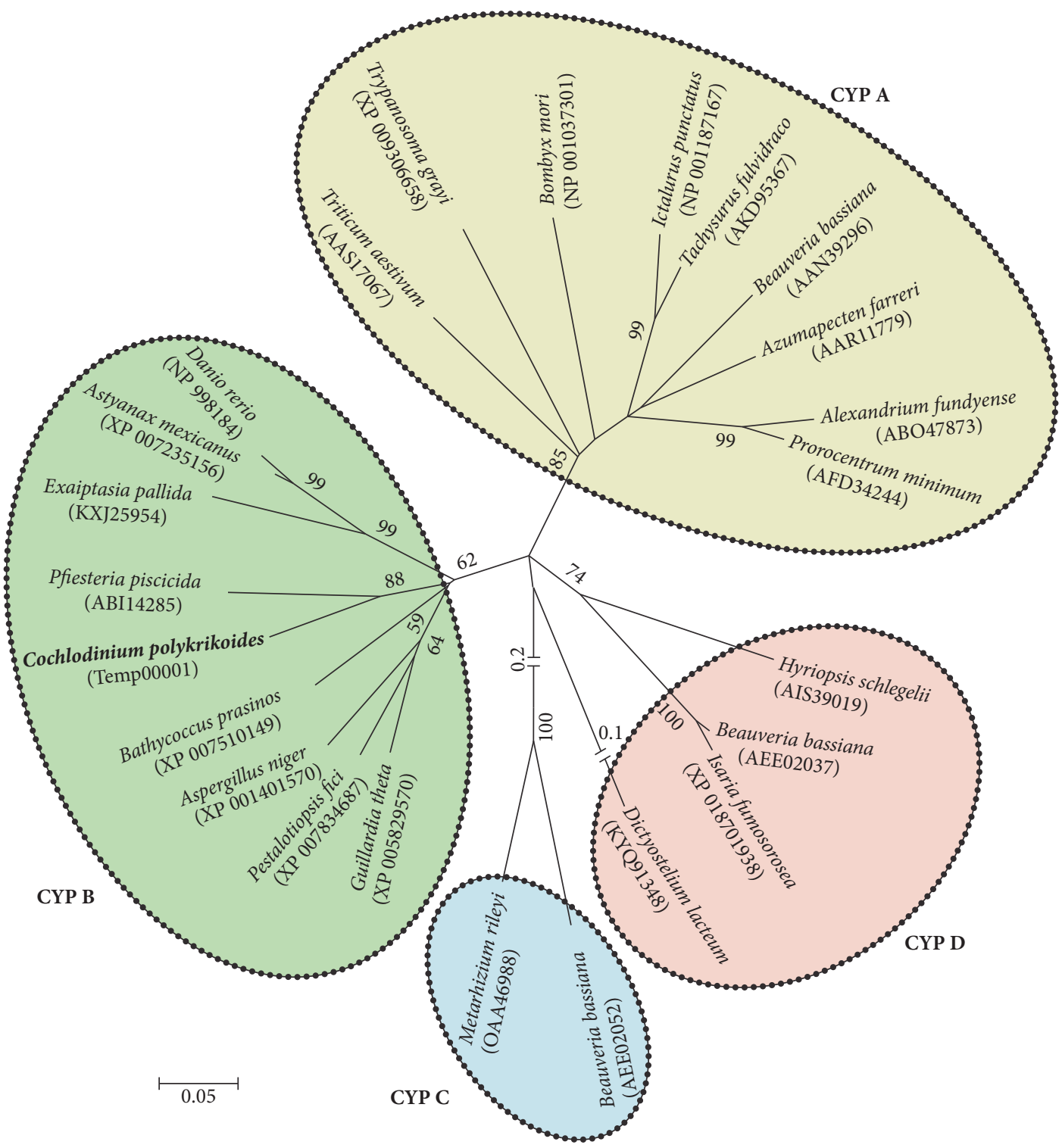

FIGURE 4: Phylogenic tree of CPCYP with other eukaryotic CYP proteins. The analysis was performed with MEGA5 (bootstrap method with 1,000 replicates), and the space bar represents the number of amino acid substitutions per site. C. polykrikoides is marked in bold.

In addition, a neighbor-joining $(\mathrm{NJ})$ tree of CYPs displayed eukaryotic origin of CpCYP and divided four major clades as follows: CYP A clade (including dinoflagellates Prorocentrum minimum and Alexandrium fundyense and bivalve Azumapecten farreri), CYP B clade (including chlorophyte Bathycoccus prasinos and dinoflagellate Pfiesteria piscicida), CYP C clade (fungi Beauveria bassiana and Metarhizium rileyi), and CYP D (including fungus Beauveria bassiana and bivalve Hyriopsis schlegelii) (Figure 4). Similar results were obtained in the phylogenetic analysis of the red algae Griffithsia japonica, where CYPs from different species that belonged to the same CYP group were more closely related to each other than to CYPs from the same species in different groups [20]. These results confirm that the CpCYP identified in the present study (see Figure 2) belongs to cyclophilin B group, while our previous CYP identified from $P$. minimum should belong to CYP A [29]. Upon comparisons and BLAST searches, we only detected three groups (CYP A, CYP B, and CYP C) of CYPs from dinoflagellates (Figure 4), which were matched to the above results (Figure 3).

3.3. Effects of Environmental Stressors and Photosynthetic Efficiency. Prior to CYP gene response of C. polykrikoides to typical contaminants, we assessed the effect of different doses of biocides $\mathrm{CuSO}_{4}$ and $\mathrm{NaOCl}$ over different exposure times, using some physiological parameters, including cell count, chlorophyll $a$ levels, and photosynthetic efficiency. Cell count exhibited similar decreasing patterns in C. polykrikoides after 6 and $72 \mathrm{~h}$ exposure to $\mathrm{CuSO}_{4}$ and $\mathrm{NaOCl}$ (Figures $5(\mathrm{a})$ and $5(\mathrm{~b}))$. After $6 \mathrm{~h}$ treatment, cell counts showed a significant decrease at the relatively higher concentrations $(P<0.05)$. Furthermore, after $72 \mathrm{~h}$ treatment, a significant 


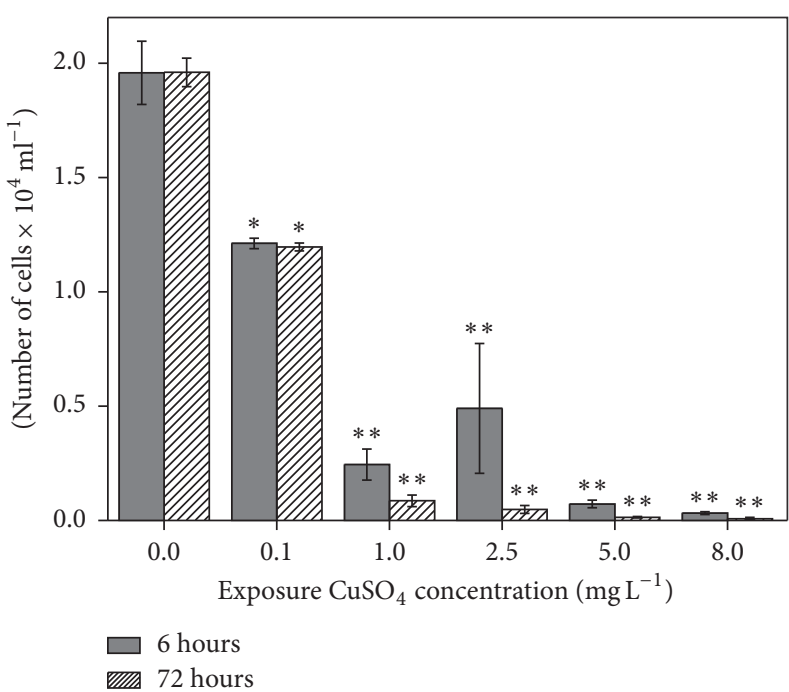

(a)

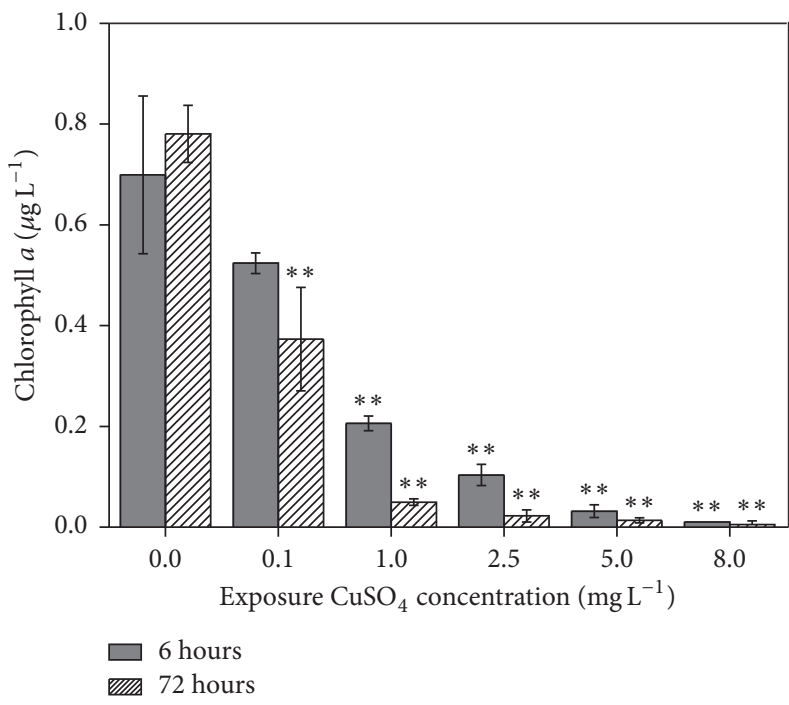

(c)

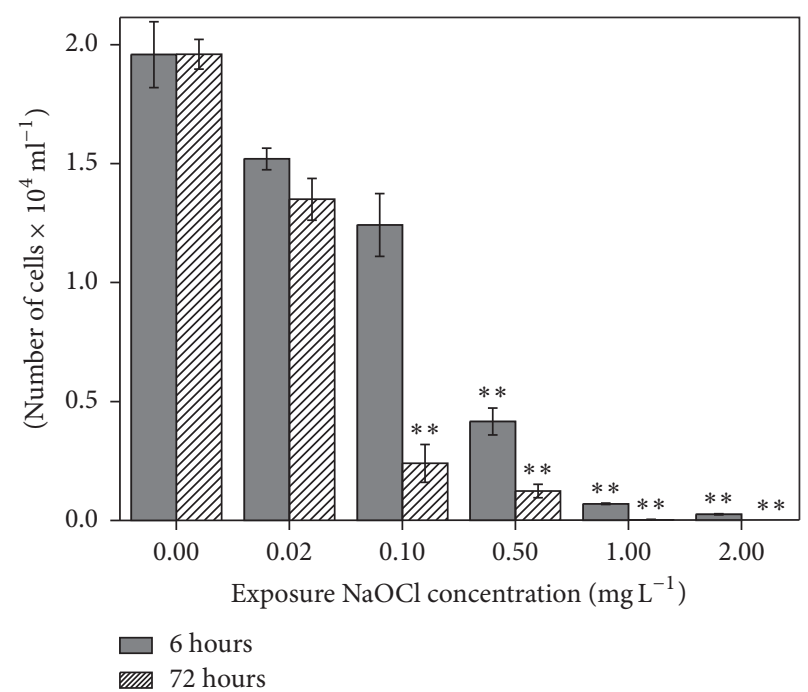

(b)

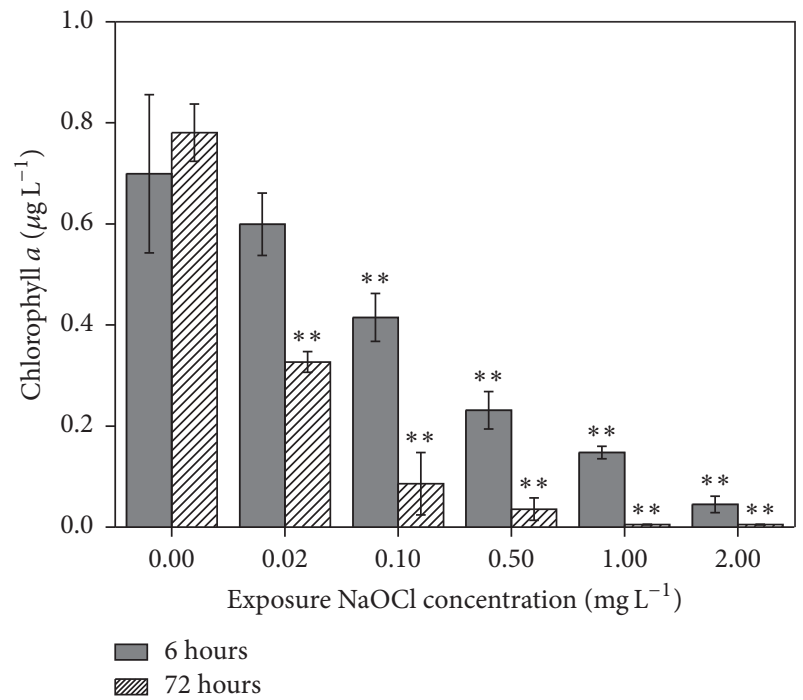

(d)

FIGURE 5: Variation in the number of cells $(\mathrm{a}, \mathrm{b})$ and chlorophyll $a$ level $(\mathrm{c}, \mathrm{d})$ of C. polykrikoides after 6 and $72 \mathrm{~h}$ of exposure to biocides CuSO 4 and $\mathrm{NaOCl}$. Significant differences between the control and treated sample, as determined by one-way ANOVA, are highlighted. ${ }^{*} P<0.05$; ${ }^{* *} P<0.01$.

reduction was observed, with more than $90 \%$ reduction. Such growth retardation effect is similar to those examined from the chlorophytes Chlorella vulgaris [45] and Closterium ehrenbergii [46] and the dinoflagellate P. minimum [47].

In addition to this, chlorophyll $a$ levels showed a similar trend to cell count (Figures 5(c) and 5(d)). Similar to the present study, several reports $[45,46,48]$ showed the inhibition of chlorophyll $a$ content of algae by environmental contaminants. For example, Dia et al. [49] reported a doseand time-dependent decrease in chlorophyll $a$ levels of the blue-green algae Microcystis aeruginosa when exposed to $\mathrm{CuSO}_{4}$.

As for photosynthetic efficiency $(F v / F m)$, the results showed a dose-dependent reduction in response to $\mathrm{CuSO}_{4}$ and $\mathrm{NaOCl}$. At $6 \mathrm{~h}$ exposure, $\mathrm{Fv} / \mathrm{Fm}$ was slightly decreased with increased $\mathrm{CuSO}_{4}$ and $\mathrm{NaOCl}$ concentration. However, after $24 \mathrm{~h}$ incubation, the cells exposed to $\mathrm{CuSO}_{4}$ showed a much more significant decrease than those exposed to $\mathrm{NaOCl}$ ( 0.3 and 0.4 at $1.0 \mathrm{mg} \mathrm{L}^{-1}$ for $\mathrm{CuSO}_{4}$ and $\mathrm{NaOCl}$, resp.) (Figure 6). Our findings on inhibition of photosynthetic efficiency by environmental stress are in accordance with those observed by Guo et al. $[38,50]$ and Rocchetta and Küpper [51].

3.4. Effect of Toxic Chemicals on Transcription of CpCYP. In this study, the transcriptional expression of $C p C Y P$ showed a different expression pattern after exposure to $\mathrm{CuSO}_{4}$ and $\mathrm{NaOCl}$. In the case of exposure to $\mathrm{CuSO}_{4}$, the transcriptional expression level of $C P C Y P$ was significantly upregulated $(P<$ 0.01 ), depending on the doses, showing 2.5- and 3.4-fold 


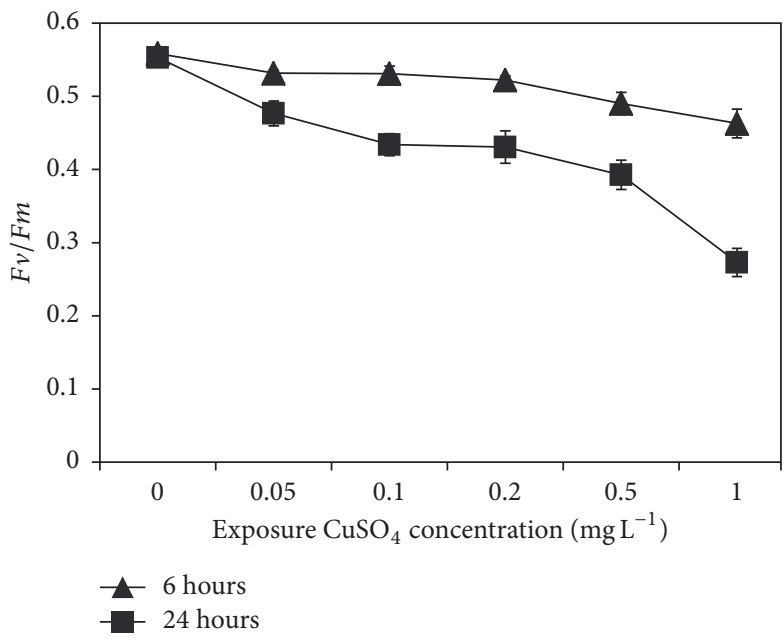

(a)

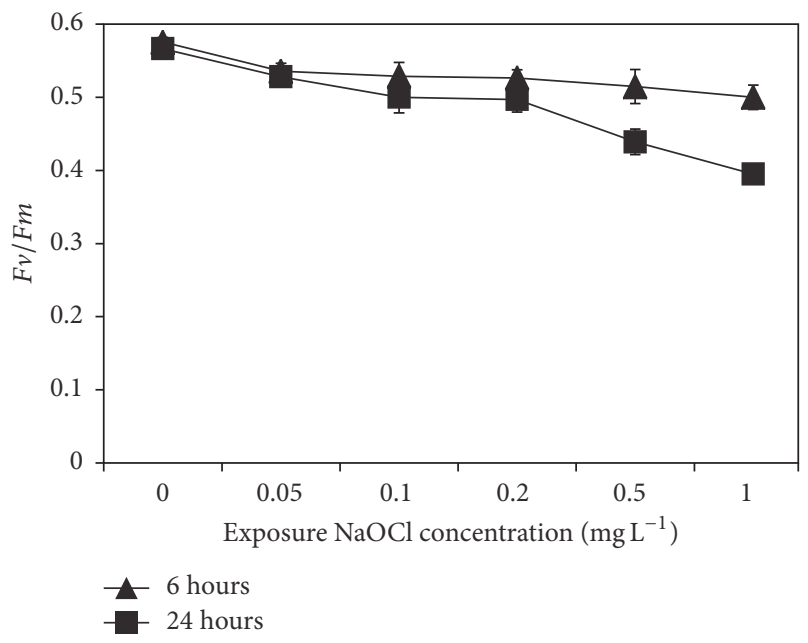

(b)

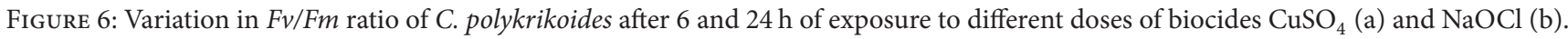

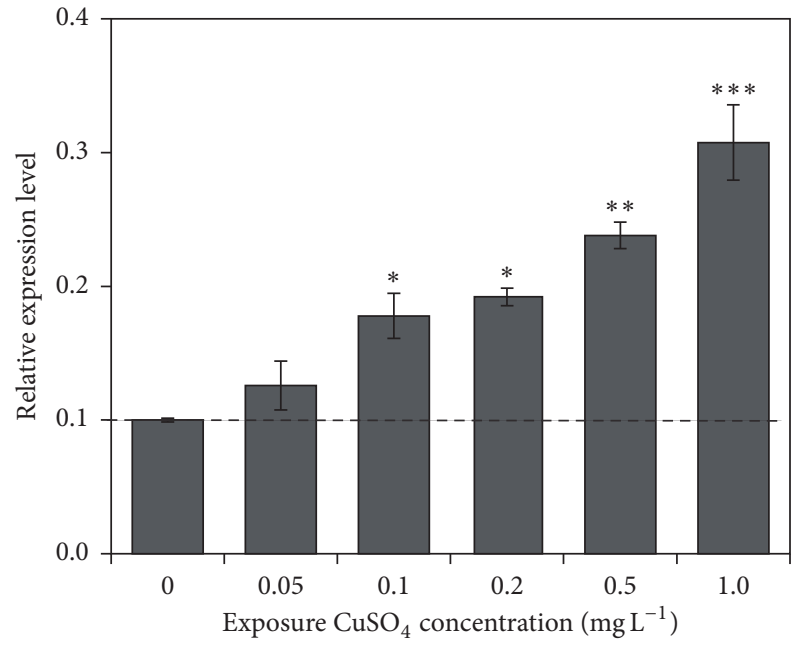

(a)

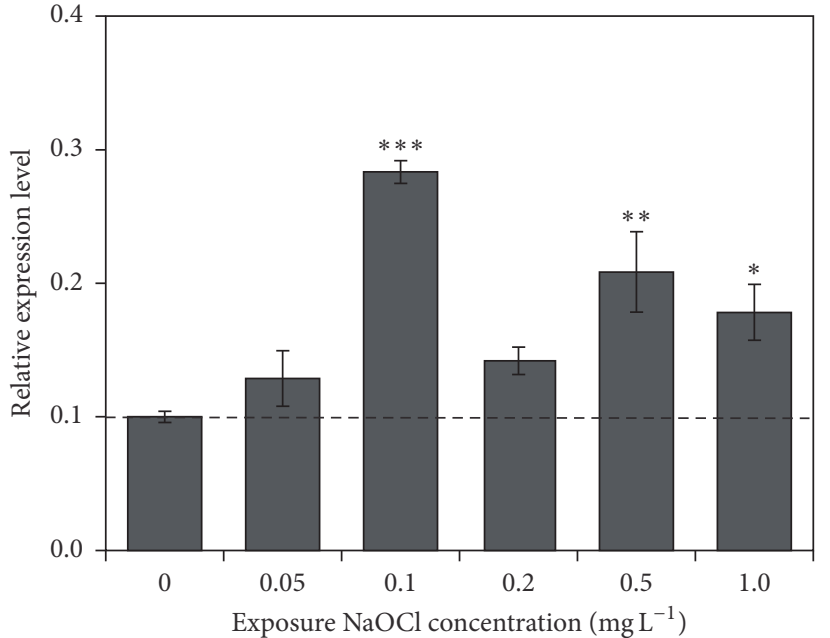

(b)

Figure 7: Effect of biocide pollutants $\mathrm{CuSO}_{4}(\mathrm{a})$ and $\mathrm{NaOCl}(\mathrm{b})$ on the expression of $C P C Y P$. Significant differences between the control and treated sample, as determined by one-way ANOVA, are highlighted. ${ }^{*} P<0.05 ;{ }^{* *} P<0.01 ;{ }^{* * *} P<0.001$.

changes at 0.5 and $1.0 \mathrm{mg} \mathrm{L}^{-1} \mathrm{CuSO}_{4}$, respectively, compared to that of the control. However, after $\mathrm{NaOCl}$ exposure, the transcriptional level was first increased, with 2.9- and 2.1-fold changes under 0.1 and $0.5 \mathrm{mg} \mathrm{L}^{-1} \mathrm{NaOCl}$ treatments, respectively, and then decreased at relatively higher concentrations (Figure 7). Along with these results, it is clearly revealed that $C p C Y P$ gene expression is induced by biocide pollutants $\mathrm{CuSO}_{4}$ and $\mathrm{NaOCl}$, but the expression patterns may depend on the dose and nature of toxicant. Our results on transcript abundance of CYP are in accordance with those of previous reports [52, 53]. For example, $\mathrm{Wu}$ and Lee [54] reported that the CYP transcription showed changes after exposure to excess copper in the marine macroalgae Ulva fasciata. In addition, Ponmani et al. [29] indicated that the gene expression of CYP in Prorocentrum minimum was significantly induced upon exposure to common pollutants (copper, sodium nitroprusside, and polychlorinated biphenyl). Taken together, upregulation of $C P C Y P$ in C. polykrikoides indicated its important role in stress-defense responses rather than previously known housekeeping functions.

3.5. Implications of the Dinoflagellate CYP. Dinoflagellates live in diverse habitats and seasons, and thus they are subjected to varied stressful conditions (e.g., water temperature changes, UV, and sudden exposure to toxic contaminants). These environmental stressors may be responsible for oxidative stress in cells [55], and in that case antioxidant proteins intervene as part of the cell's survival strategy. In the dinoflagellate C. polykrikoides, specific antioxidant genes and/or proteins, such as superoxide dismutase (SOD) and glutathione reductase (GR), have been detected by using large-scale transcriptome analysis of dinoflagellates [38]. 
In addition, we have discovered certain antioxidant genes, including catalase-peroxidase gene (KatG), GST, and HSPs, which were suggested to be involved in the response of the cells protection against environmental toxicants $[42,55,56]$. The previous and present studies indicated that $C p C Y P$ might play a crucial role in combating environmental stress and facilitating molecular adaptation.

In addition, considering the expression level change of $C p C Y P$ by various environmental pollutants (such as heavy metals and biocide chlorine), it could be used as an early and rapid warning biomarker in ecotoxicity assessments [29].

In conclusion, this study determined the full-length sequence of cyclophilin from the harmful dinoflagellate $C$. polykrikoides. In addition, we characterized gene structure and phylogenetic affiliations to other CYPs and investigated the conserved motifs and signal peptides to determine the classification of cyclophilin type in dinoflagellates. Moreover, the transcriptional expressions of $C p C Y P$ were induced by biocide pollutants $\mathrm{CuSO}_{4}$ and $\mathrm{NaOCl}$. These results combined shed light on the function of cyclophilins, to be more than a housekeeping gene, and the possibility of use as an ecotoxicity assessments biomarker. Further studies are necessary to identify different cyclophilin groups and the relationship between them and also reveal the effect of other toxicants on expressional responses in dinoflagellates.

\section{Conflicts of Interest}

The authors declare that there are no conflicts of interest regarding the publication of this paper.

\section{Acknowledgments}

The authors would like to thank Dr. R. Guo for the experimental assistance and Dr. R. Sathasivam for the English editing and critical comments on the early version of the manuscript. This work was supported by the National Research Foundation of Korea Grant funded by the Korean Government (2015M1A5A1041805 and 2016R1D1A1A09920198) and by a grant from the National Institute of Fisheries Science (R2017047) funded to J.-S. Ki.

\section{References}

[1] D. M. Anderson, "The ecology and oceanography of harmful algal blooms: multidisciplinary approaches to research and management," IOC Technical Series IOC/2007/TS/74, UNESCO, 2007.

[2] Y. S. Lee and S. Y. Lee, "Factors affecting outbreaks of Cochlodinium polykrikoides blooms in coastal areas of Korea," Marine Pollution Bulletin, vol. 52, no. 6, pp. 626-634, 2006.

[3] R. M. Kudela and C. J. Gobler, "Harmful dinoflagellate blooms caused by Cochlodinium sp.: global expansion and ecological strategies facilitating bloom formation," Harmful Algae, vol. 14, pp. 71-86, 2012.

[4] R. V. Azanza, L. T. David, R. T. Borja, I. U. Baula, and Y. Fukuyo, "An extensive Cochlodinium bloom along the western coast of Palawan, Philippines," Harmful Algae, vol. 7, no. 3, pp. 324-330, 2008.
[5] C. J. Gobler, D. L. Berry, O. R. Anderson et al., "Characterization, dynamics, and ecological impacts of harmful Cochlodinium polykrikoides blooms on eastern Long Island, NY, USA," Harmful Algae, vol. 7, no. 3, pp. 293-307, 2008.

[6] Y. Z. Tang and C. J. Gobler, "Cochlodinium polykrikoides blooms and clonal isolates from the northwest Atlantic coast cause rapid mortality in larvae of multiple bivalve species," Marine Biology, vol. 156, no. 12, pp. 2601-2611, 2009.

[7] S. Moreno Díaz de la Espina, E. Alverca, A. Cuadrado, and S. Franca, "Organization of the genome and gene expression in a nuclear environment lacking histones and nucleosomes: The amazing dinoflagellates," European Journal of Cell Biology, vol. 84, no. 2-3, pp. 137-149, 2005.

[8] A. Moustafa, A. N. Evans, D. M. Kulis et al., "Transcriptome profiling of a toxic dinoflagellate reveals a gene-rich protist and a potential impact on gene expression due to bacterial presence," PLoS ONE, vol. 5, no. 3, Article ID e9688, 2010.

[9] H. Zhang, Y. Hou, L. Miranda et al., "Spliced leader RNA transsplicing in dinoflagellates," Proceedings of the National Acadamy of Sciences of the United States of America, vol. 104, no. 11, pp. 4618-4623, 2007.

[10] S. A. Brunelle and F. M. Van Dolah, "Post-transcriptional regulation of S-Phase genes in the dinoflagellate, karenia brevis," Journal of Eukaryotic Microbiology, vol. 58, no. 4, pp. 373-382, 2011.

[11] J. D. Hackett, D. M. Anderson, D. L. Erdner, and D. Bhattacharya, "Dinoflagellates: a remarkable evolutionary experiment," American Journal of Botany, vol. 91, no. 10, pp. 1523-1534, 2004.

[12] S. Lin, "Genomic understanding of dinoflagellates," Research in Microbiology, vol. 162, no. 6, pp. 551-569, 2011.

[13] J. H. Wisecaver and J. D. Hackett, "Dinoflagellate genome evolution," Annual Review of Microbiology, vol. 65, pp. 369-387, 2011.

[14] R. Guo and J.-S. Ki, "Differential transcription of heat shock protein 90 (HSP90) in the dinoflagellate Prorocentrum minimum by copper and endocrine-disrupting chemicals," Ecotoxicology, vol. 21, no. 5, pp. 1448-1457, 2012.

[15] E. Shoguchi, C. Shinzato, T. Kawashima et al., "Draft assembly of the symbiodinium minutum nuclear genome reveals dinoflagellate gene structure," Current Biology, vol. 23, no. 15, pp. 13991408, 2013.

[16] A. Galat, "Peptidylprolyl cis/trans isomerases (immunophilins): biological diversity-targets-functions," Current Topics in Medicinal Chemistry, vol. 3, no. 12, pp. 1315-1347, 2003.

[17] A. R. Marks, “Cellular functions of immunophilins," Physiological Reviews, vol. 76, no. 3, pp. 631-649, 1996.

[18] R. E. Handschumacher, M. W. Harding, J. Rice, R. J. Drugge, and D. W. Speicher, "Cyclophilin: a specific cytosolic binding protein for cyclosporin A," Science, vol. 226, no. 4674, pp. 544$547,1984$.

[19] J. Dornan, P. Taylor, and M. D. Walkinshaw, "Structures of immunophilins and their ligand complexes.", Current Topics in Medicinal Chemistry, vol. 3, no. 12, pp. 1392-1409, 2003.

[20] Y. K. Lee, C. B. Hong, Y. Suh, and I. K. Lee, "A cDNA clone for cyclophilin from Griffithsia japonica and phylogenetic analysis of cyclophilins," Molecules and Cells, vol. 13, no. 1, pp. 12-20, 2002.

[21] S. Kumari, S. Roy, P. Singh, S. L. Singla-Pareek, and A. Pareek, "Cyclophilins: proteins in search of function," Plant Signaling and Behavior, vol. 8, no. 1, p. e22734, 2013. 
[22] Q. Yao, M. Li, H. Yang, H. Chai, W. Fisher, and C. Chen, "Roles of cyclophilins in cancers and other organ systems," World Journal of Surgery, vol. 29, no. 3, pp. 276-280, 2005.

[23] K. Arora, W. M. Gwinn, M. A. Bower et al., "Extracellular cyclophilins contribute to the regulation of inflammatory responses," The Journal of Immunology, vol. 175, no. 1, pp. 517$522,2005$.

[24] H. Hoffmann and C. Schiene-Fischer, "Functional aspects of extracellular cyclophilins," biological chemistry, vol. 395, no. 7-8, pp. 721-735, 2014.

[25] T.-M. Wu, Y.-T. Hsu, M.-S. Sung, Y.-T. Hsu, and T.-M. Lee, "Expression of genes involved in redox homeostasis and antioxidant defense in a marine macroalga Ulva fasciata by excess copper," Aquatic Toxicology, vol. 94, no. 4, pp. 275-285, 2009.

[26] Z. Jia, J. Niu, L. Huan, X. Wu, G. Wang, and Z. Hou, "Cyclophilin Participates in Responding to Stress Situations in Porphyra haitanensis (Bangiales, Rhodophyta)," Journal of Phycology, vol. 49, no. 1, pp. 194-201, 2013.

[27] J. N. Bouchard and H. Yamasaki, "Implication of nitric oxide in the heat-stress-induced cell death of the symbiotic alga Symbiodinium microadriaticum," Marine Biology, vol. 156, no. 11, pp. 2209-2220, 2009.

[28] S. Perez and V. Weis, "Cyclophilin and the regulation of symbiosis in Aiptasia pallida," The Biological Bulletin, vol. 215, no. 1, pp. 63-72, 2008.

[29] T. Ponmani, R. Guo, and J.-S. Ki, "A novel cyclophilin gene from the dinoflagellate Prorocentrum minimum and its possible role in the environmental stress response," Chemosphere, vol. 139, pp. 260-267, 2015.

[30] M. G. Murray and W. F. Thompson, "Rapid isolation of high molecular weight plant DNA," Nucleic Acids Research, vol. 8, no. 19, pp. 4321-4326, 1980.

[31] T. A. Hall, "BioEdit: a user-friendly biological sequence alignment editor and analysis program for Windows 95/98/ NT," Nucleic Acids Symposium Series, vol. 41, pp. 95-98, 1999.

[32] K. Tamura, D. Peterson, N. Peterson, G. Stecher, M. Nei, and S. Kumar, "MEGA5: molecular evolutionary genetics analysis using maximum likelihood, evolutionary distance, and maximum parsimony methods," Molecular Biology and Evolution, vol. 28, no. 10, pp. 2731-2739, 2011.

[33] N. Saitou and M. Nei, “The neighbor-joining method: a new method for reconstructing phylogenetic trees," Molecular Biology and Evolution, vol. 4, no. 4, pp. 406-425, 1987.

[34] J. Felsenstein, "Confidence limits on phylogenies: an approach using the bootstrap," Evolution, vol. 39, pp. 783-791, 1985.

[35] D. T. Jones, W. R. Taylor, and J. M. Thornton, "The rapid generation of mutation data matrices from protein sequences," Computer Applications in the Biosciences, vol. 8, no. 3, pp. 275282, 1992.

[36] N. R. Baker, "Chlorophyll fluorescence: a probe of photosynthesis in vivo," Annual Review of Plant Biology, vol. 59, pp. 89-113, 2008.

[37] V. Ebenezer, W. A. Lim, and J.-S. Ki, "Effects of the algicides $\mathrm{CuSO}_{4}$ and $\mathrm{NaOCl}$ on various physiological parameters in the harmful dinoflagellate Cochlodinium polykrikoides," Journal of Applied Phycology, vol. 26, no. 6, pp. 2357-2365, 2014.

[38] R. Guo, H. Wang, Y. S. Suh, and J.-S. Ki, “Transcriptomic profiles reveal the genome-wide responses of the harmful dinoflagellate Cochlodinium polykrikoides when exposed to the algicide copper sulfate," BMC Genomics, vol. 17, no. 1, article no. 29, 2016.
[39] M. W. Pfaffl, "A new mathematical model for relative quantification in real-time RT-PCR.," Nucleic Acids Research, vol. 29, no. 9, article e45, 2001.

[40] D.-H. Lee, M. Mittag, S. Sczekan, D. Morse, and J. W. Hastings, "Molecular cloning and genomic organization of a gene for luciferin-binding protein from the dinoflagellate Gonyaulax polyedra," The Journal of Biological Chemistry, vol. 268, no. 12, pp. 8842-8850, 1993.

[41] O. K. Okamoto, L. Liu, D. L. Robertson, and J. W. Hastings, "Members of a dinoflagellate luciferase gene family differ in synonymous substitution rates," Biochemistry, vol. 40, no. 51, pp. 15862-15868, 2001.

[42] R. Guo, S. H. Youn, and J.-S. Ki, "Heat shock protein 70 and 90 genes in the harmful dinoflagellate Cochlodinium polykrikoides: genomic structures and transcriptional responses to environmental stresses," International Journal of Genomics, vol. 2015, Article ID 484626, 12 pages, 2015.

[43] G. Frigerio and H. R. B. Pelham, "A Saccharomyces cerevisiae cyclophilin resident in the endoplasmic reticulum," Journal of Molecular Biology, vol. 233, no. 1, pp. 183-188, 1993.

[44] H. Yokoi, Y. Shimizu, H. Anazawa, C. A. Lefebvre, R. G. Korneluk, and J.-E. Ikeda, "The structure and complete nucleotide sequence of the human cyclophilin 40 (PPID) gene," Genomics, vol. 35, no. 3, pp. 448-455, 1996.

[45] R. Kebeish, Y. El-Ayouty, and A. Husain, "Effect of copper on growth, bioactive metabolites, antioxidant enzymes and photosynthesis-related gene transcription in Chlorella vulgaris," World Journal of Biology and Biological Sciences, vol. 2, pp. 034-043, 2014.

[46] R. Sathasivam, V. Ebenezer, R. Guo, and J.-S. Ki, "Physiological and biochemical responses of the freshwater green algae Closterium ehrenbergii to the common disinfectant chlorine," Ecotoxicology and Environmental Safety, vol. 133, pp. 501-508, 2016.

[47] V. Ebenezer and J. Ki, "Toxic effects of Aroclor 1016 and bisphenol A on marine green algae Tetraselmis suecica, diatom Ditylum brightwellii and dinoflagellate Prorocentrum minimum," The Korean Journal of Microbiology, vol. 52, no. 3, pp. 306-312, 2016.

[48] H. Chen, J. Chen, Y. Guo, Y. Wen, J. Liu, and W. Liu, "Evaluation of the role of the glutathione redox cycle in $\mathrm{Cu}$ (II) toxicity to green algae by a chiral perturbation approach," Aquatic Toxicology, vol. 120-121, pp. 19-26, 2012.

[49] S. Dia, I. Alameddine, D. Salam, and M. El-Fadel, “ Controlling Microcystis aeruginosa blooms in a freshwater system: a comparative assessment across three chemical algaecides ," in Proceedings of the WATER POLLUTION 2016, pp. 139-149, Venice, Italy, June 2016.

[50] R. Guo, V. Ebenezer, H. Wang, and J.-S. Ki, “Chlorine affects photosystem II and modulates the transcriptional levels of photosynthesis-related genes in the dinoflagellate Prorocentrum minimum," Journal of Applied Phycology, vol. 29, no. 1, pp. 153-163, 2017.

[51] I. Rocchetta and H. Küpper, "Chromium- and copper-induced inhibition of photosynthesis in Euglena gracilis analysed on the single-cell level by fluorescence kinetic microscopy," New Phytologist, vol. 182, no. 2, pp. 405-420, 2009.

[52] I.-S. Kim, S.-Y. Shin, Y.-S. Kim et al., "Expression of yeast cyclophilin A (Cprl) provides improved stress tolerance in Escherichia coli," Journal of Microbiology and Biotechnology, vol. 20, no. 6, pp. 974-977, 2010. 
[53] M. Milan, S. Ferraresso, C. Ciofi et al., "Exploring the effects of seasonality and chemical pollution on the hepatopancreas transcriptome of the Manila clam," Molecular Ecology, vol. 22, no. 8, pp. 2157-2172, 2013.

[54] T.-M. Wu and T.-M. Lee, "Regulation of activity and gene expression of antioxidant enzymes in Ulva fasciata Delile (Ulvales, Chlorophyta) in response to excess copper," Phycologia, vol. 47, no. 4, pp. 346-360, 2008.

[55] R. Guo, V. Ebenezer, and J.-S. Ki, "PmMGST3, a novel microsomal glutathione S-transferase gene in the dinoflagellate Prorocentrum minimum, is a potential biomarker of oxidative stress," Gene, vol. 546, no. 2, pp. 378-385, 2014.

[56] R. Guo and J.-S. Ki, "Characterization of a novel catalaseperoxidase (KATG) gene from the dinoflagellate Prorocentrum minimum," Journal of Phycology, vol. 49, no. 5, pp. 1011-1016, 2013. 

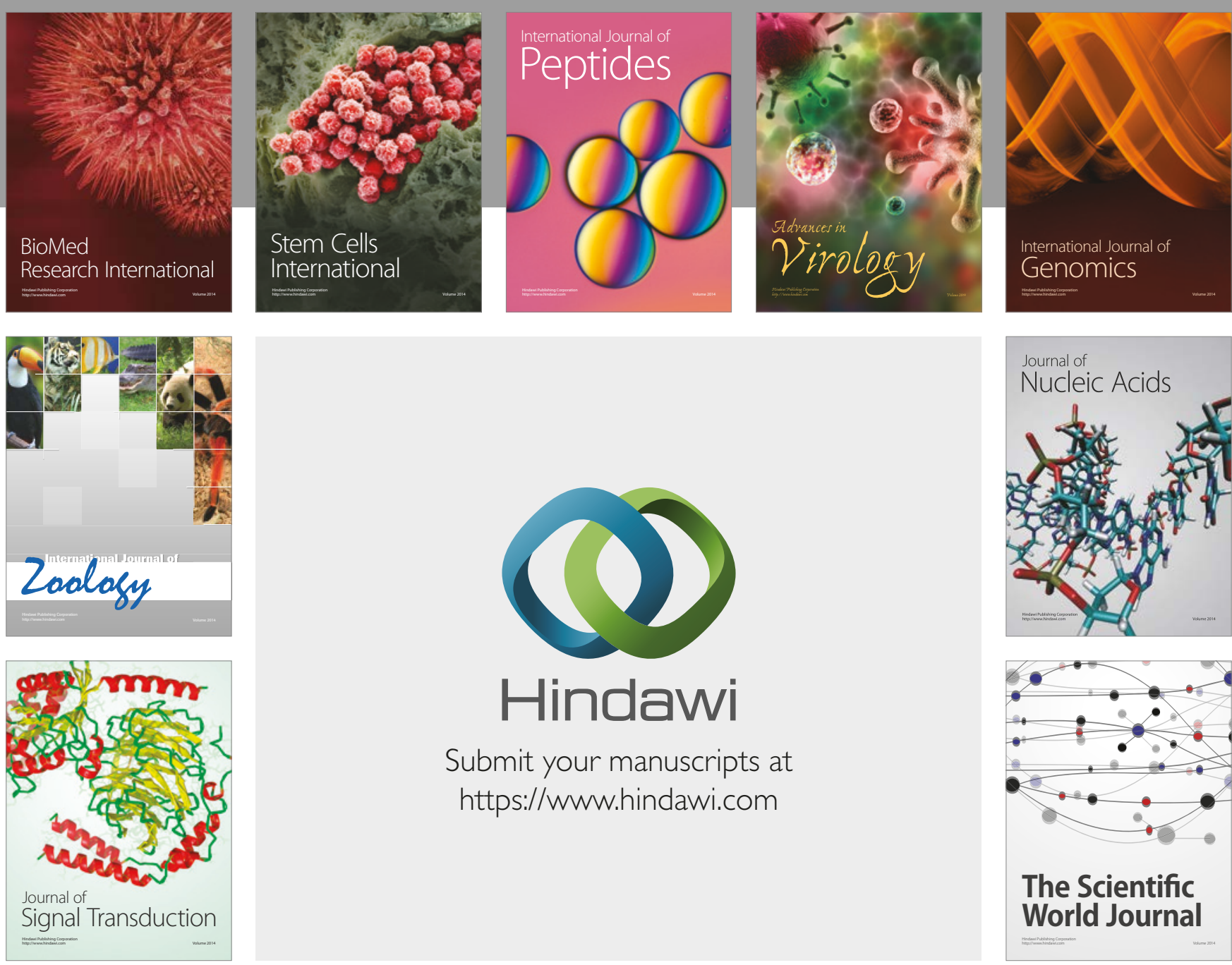

Submit your manuscripts at

https://www.hindawi.com
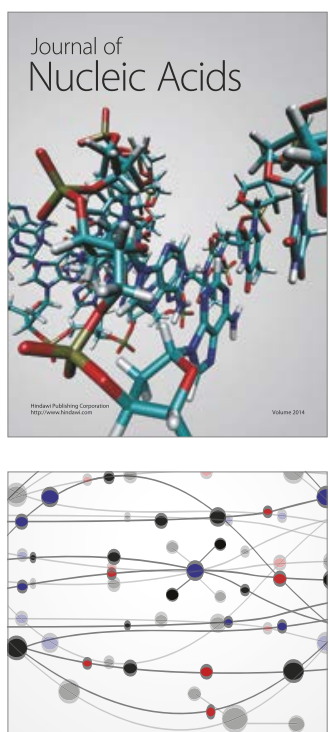

The Scientific World Journal

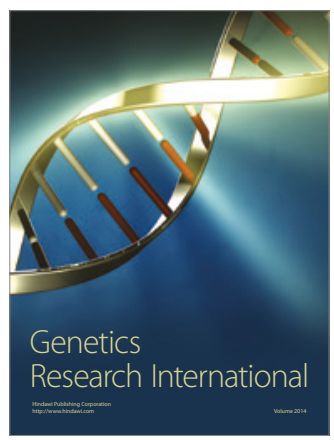

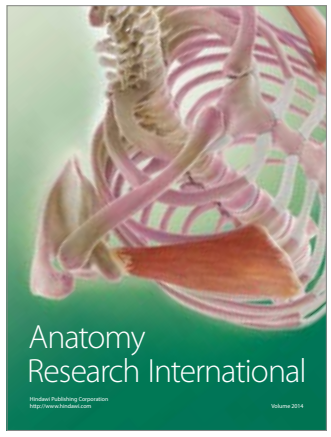

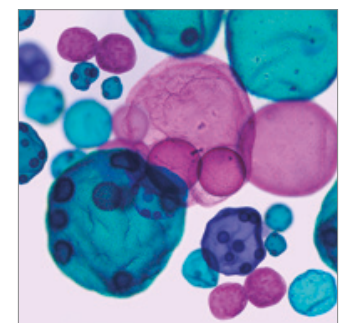

International Journal of Microbiology
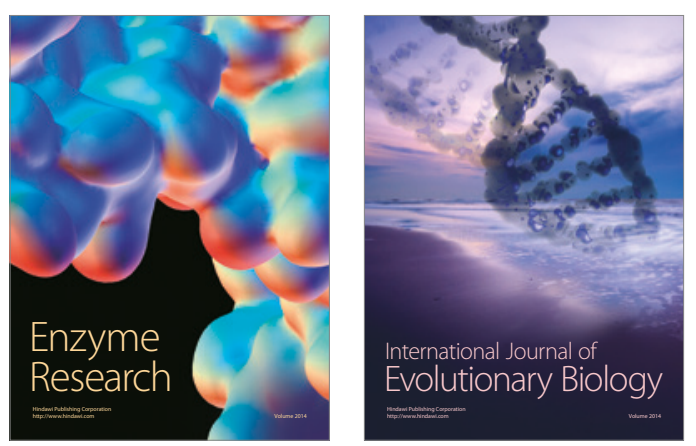
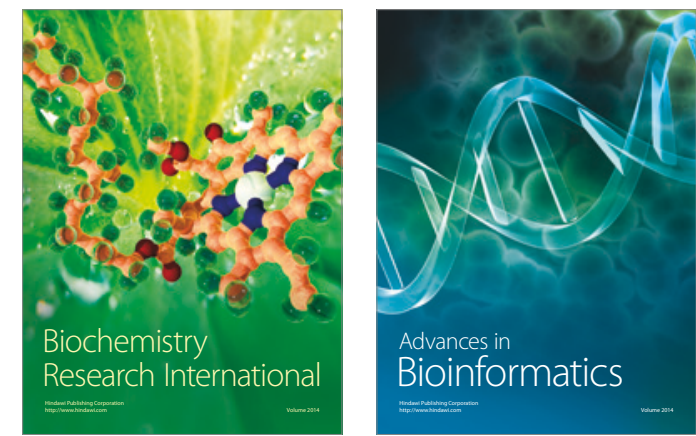

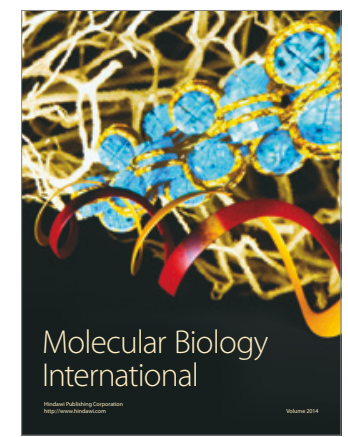

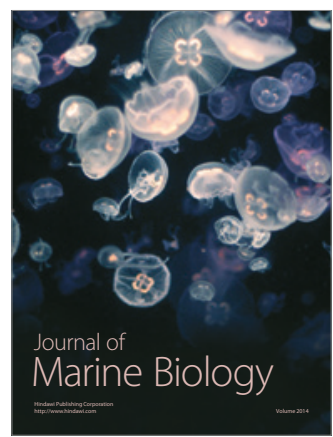

